\title{
Tutela da Evidência: Efetividade versus Desuso
}

\author{
The Evidence Protection: Effectiveness versus Disuse \\ Custodia de Evidencia: Efectividad versus Desuso
}

Recebido: 05/12/2021 | Revisado: 10/12/2021 | Aceito: 14/12/2021 | Publicado: 21/12/2021

\author{
Bruno Martins Duarte Ortiz \\ ORCID: https://orcid.org/0000-0002-7171-6415 \\ Universidade Paranaense, Brasil \\ E-mail: bruno.ortiz.adv@hotmail.com \\ Marcelo de Alencar Moura Fé \\ ORCID: https://orcid.org/0000-0002-7794-1613 \\ Universidade Paranaense, Brasil \\ E-mail: marcelo.fe@edu.unipar.br \\ José Miguel Garcia Medina \\ ORCID: https://orcid.org/0000-0002-3669-5145 \\ Universidade Paranaense, Brasil \\ E-mail: medina@medina.adv.br
}

\begin{abstract}
Resumo
O presente ensaio tem como finalidade analisar o instituto da tutela de evidência e demonstrar a sua eficácia na prática forense. Aborda-se a origem e evolução histórica das tutelas provisórias, com enfoque na tutela da evidência e a evolução legislativa do instituto. Objetiva-se averiguar as razões de o instituto ser tão pouco utilizado na prática forense. São apresentados diversos exemplos de tutela de evidência e de qual maneira os operadores do direito podem se valer do instituto para maior eficácia da tutela jurisdicional. O estudo baseia-se na metodologia dedutiva de bibliografias e das legislações. Ao final da pesquisa, conclui-se que apesar de o instituto já existir há tempos em nosso ordenamento, possivelmente seu desuso se atribui à uma questão cultural, já que a maior parte da comunidade jurídica ao se deparar em tutelas provisórias, apenas se recordam das tutelas provisórias de urgência, muitas vezes se esquecendo da tutela da evidência e sua efetividade.
\end{abstract}

Palavras-chave: Tutela provisória; Tutela da evidência; Cognição sumária; Efetividade; CPC/2015.

\begin{abstract}
The present work aims to analyze the evidence protection technique and its effectiveness in forensic practice. Approach the origins and historical evolution of the temporary protections, focusing on the evidence and its legal evolution. Aim to inquire the low usage reasons of the institute. Its presented some ways examples that law operators can use the institute to achieve more effectiveness in judicial proceedings. The study is based on deductive methodology by bibliographics and legislation. At the end of the study, it concludes that even though the institute exists for a long time, probably its disuse relates to a cultural issue, since the most part of the legal community just remembers the urgency protection and forgot about the evidence protection and its effectiveness.
\end{abstract}

Keywords: Temporary protection; Evidence protection; Summary cognition; Effectiveness; CPC/2015.

\section{Resumen}

Este trabajo tiene como finalidade examinar el instituto de la custodia de evidencia y demostrar su eficacia juridica. Trata de la origen y evolucion historica de las custodias temporarias, con foco en la custodia de evidencia y la evolucion legislativa del instituto. Con el objetivo de descobrir las razones por las cuales el instituto es tan poco usado. Se presenta varios ejemplos de custodia de evidencia e cuales formas los profesionales de derecho pueden valerse para mayor efetividade de la tutela jurisdicional. El estudo se basa en metodología dedutiva de bibliografía y legislaciones. Al final de la pesquisa, se concluye que por más que el instituto exista hace mucho tempo, quizás su desuso se asigna a una cuestión cultural, ya que la maioría de la comunidade jurídica cuando se depara com custodias temporarias, solo se recuerdan de las custodias temporarias de urgência, se olvidando de las custodias de evidéncia y su efetividad.

Palabras clave: Custodia Temporaria; Custodia de evidencia; Cognición sumaria; Efectividad; CPC/2015.

\section{Introdução}

A evidência de um direito e sua tutela jurisdicional é objeto de estudo há muito tempo. Na visão clássica do tempo como inimigo, aliada ao princípio constitucional da duração razoável do processo, parece inapropriado que direitos urgentes ou 
tão evidentes sejam submetidos às delongas de um procedimento voltado à realização de cognição judicial completa e exauriente, inclusive sujeito às instâncias recursais, para somente receberem proteção quando do trânsito em julgado da decisão que os reconhecer.

Nesse sentido, as tutelas provisórias desempenham papel fundamental evitando o perecimento e protegendo os detentores de direitos tão evidentes.

O CPC/2015 (Brasil, 2015) apresenta uma nova roupagem às tutelas provisórias, unificando os requisitos da tutela antecipada e da cautelar, tanto discutidos à égide do CPC/1973 (Brasil, 1973). Já as tutelas de evidência passaram a ter previsão expressa em um dispositivo próprio (artigo 311), sem, contudo, nele se exaurirem.

Ocorre que grande parte dos operadores do direito, ao pensarem em tutelas provisórias, somente se lembram das de urgência e acabam esquecendo da existência de uma modalidade de tutela provisória que independe de urgência ou perigo. A tutela de evidência ainda não vem sendo tanto invocada pelos operadores, que acabam perdendo uma chance de verem seus direitos tutelados sumariamente, sem a necessidade de se aguardar todo o trâmite de um longo processo judicial.

Analisaremos, ao longo do presente trabalho, a efetividade da tutela da evidência através de situações cotidianas em que o operador pode se valer do instrumento para satisfazer, de modo rápido, o direito pleiteado.

\section{Metodologia}

Este ensaio avalia, por meio de uma revisão integrativa, a efetividade da tutela da evidência e as formas de aplicação do instituto. A pesquisa bibliográfica é constituída de livros, artigos publicados, legislações passadas e atuais, bem como informações verbais obtidas em palestras.

As conclusões registradas neste trabalho, acerca do desuso do instituto da tutela da evidência pelos profissionais do direito, são baseadas nas experiências vividas pelos autores deste trabalho no cotidiano jurídico.

\section{Resultados e Discussão}

\subsection{Breve Histórico Das Tutelas Provisórias}

A morosidade do Poder Judiciário é um problema de longa data. A ampliação e facilitação do acesso à justiça estatal, aliada a um sistema processual repleto de recursos, acarretaram um significante aumento das demandas, o que sobrecarregou o Poder Judiciário. Isso decorre, dentre outras razões, do fato de o Judiciário não deter de estrutura suficiente ao que seria o ideal em termos de divisão de trabalho, havendo escassez de servidores e magistrados, o que favorece a morosidade.

Não obstante a isso, a justiça sempre foi caracterizada por uma certa lentidão, em razão não só à necessidade de cumprimento ao devido processo legal, mas também pela serenidade que deve acompanhar as decisões judiciais. No entanto, a celeridade judicial tornou-se a principal exigência no direito processual moderno. Se a qualidade esperada da prestação jurisdicional pressupõe tempo, apenas o tempo estritamente necessário é admissível (Strickler, 2020, p. 93-106). Afinal, nos dizeres de Rui Barbosa, justiça tardia não é justiça, senão injustiça qualificada e manifesta.

Outrossim, a fluência incontrolada do tempo é um fator de possíveis corrosões de direitos ou de inabilitação do processo a cumprir sua missão de dar efetividade a estes, solucionando conflitos e pacificando pessoas com justiça (Dinamarco, 2020a, p. 519).

Há situações concretas em que a duração do processo e a espera da composição do conflito geram prejuízos ou risco de prejuízos para uma das partes, os quais podem assumir proporções sérias, comprometendo a efetividade da tutela a cargo da Justiça. O ônus do tempo, às vezes, recai precisamente sobre aquele que se apresenta, perante o juízo, como quem se acha na condição de vantagem que afinal virá a merecer a tutela jurisdicional (Theodoro Junior, 2018, p. 646-647). 
Não se trata, aqui, das situações de urgência "normal", afinal, todos os processos se revestem de uma certa urgência. Mas sim daquelas situações que exponham a risco de lesão de grave ou difícil reparação (Marins et al., 2020, p. 149-157).

Neste cenário, as tutelas provisórias foram inseridas no ordenamento jurídico pátrio como uma técnica de sumarização ágil e eficiente na antecipação ou no resguardo legal para uma tutela principal. Para Dinamarco (2020b, p. 196), as tutelas provisórias são medidas processuais portadoras de solução a serem obtidas em breve tempo e fundadas em uma cognição sumária - seja mediante a imediata fruição integral ou parcial do bem da vida postulado, seja para de algum modo preservar certos meios exteriores necessários ao exercício frutífero da jurisdição.

No entanto, as tutelas provisórias são oriundas de um processo de intensas e longas alterações legislativas.

Essa preocupação em assegurar resultados úteis ao processo no direito brasileiro possui origens longínquas, mais especificamente no Regulamento 737, de 1850, no qual já se constatava a existência de algumas medidas cautelares (Carvalho, 2017, p. 13-31).

Em 1939, com a entrada em vigor do primeiro Código de Processo Civil brasileiro (Brasil, 1939), havia a previsão apenas das tutelas cautelares, que foram elencadas no Livro V, denominado "dos processos acessórios", mantendo-se a mesma preocupação com os danos que a resposta judicial poderia causar (Carvalho, 2017, p. 13-31).

Nesta época da história, importante registrar os ensinamentos de Enrico Túllio Liebman, considerado por muitos o "pai" da ciência processual brasileira.

Após anos de vigência do CPC/1939, a necessidade de atualização da legislação processual brasileira foi conferida a Alfredo Buzaid, um dos alunos de Liebman. Buzaid assumiu um anteprojeto e inseriu as lições aprendidas com o doutrinador italiano.

A respeito das tutelas cautelares, explicava Buzaid (1977) que Liebman criticava, à luz do CPC/1939, a ausência de um poder geral de cautela: “[...] na legislação brasileira omite-se atribuição expressa ao juiz de um poder acautelatório geral, de que ele possa se valer, segundo as necessidades e as circunstâncias fora dos casos tradicionais especialmente previstos".

Seguindo a teoria de seu mestre, Buzaid isolou o processo cautelar das demais, destinando-lhe um capítulo próprio. O livro destinado às cautelares (Livro III, Do processo Cautelar), com título único "Das Medidas Cautelares", foi dividido em dois capítulos. O primeiro capítulo, artigos 796 a 812, continha as disposições gerais com os pressupostos básicos de cada provimento cautelar.

No art. 798, constava o poder geral de cautela, oriundo da crítica de Liebman. No segundo capítulo, artigos 813 a 889 , estavam dispostas 14 cautelares específicas. Notava-se, claramente, a semelhança entre o CPC/1973 e o Código de Processo Civil italiano.

Ocorre que, ainda assim, até o final do século XX (mais precisamente, até a reforma de 1994, como adiante se verá), o CPC/1973 não previa nenhuma tutela satisfativa geral, que concedesse a fruição do direito de maneira antecipada (havia, tão somente, procedimentos especiais que a admitiam, como o dedicado às ações possessórias). As medidas cautelares, de acordo com o texto legal então em vigor, somente asseguravam o direito, que era entregue no final da demanda.

Em razão disso, os operadores passaram a utilizar da tutela cautelar como mecanismo a se obter tutela satisfativa. Situou-se a questão de se saber se as medidas cautelares eram apenas consistentes de garantias ou se, ao revés poderiam comportar também providências que representassem a própria antecipação do direito material afirmado pelo interessado, ou seja, questionou-se largamente a legitimidade ou não do que ficou conhecido como medidas cautelares satisfativas (Zavascki, 1996, p. 35-51).

Nas lições de Watanabe (1996, p. 25): 
A inexistência de instrumento processual adequado para a tutela desses direitos, somada à irritante e desesperadora lentidão da Justiça, provocada por fatores múltiplos, estimulou a criatividade dos operadores do direito, que passaram a utilizar intensamente da ação cautelar inominada como um meio de obtenção da tutela postulada ou a ser postulada na chamada 'ação principal'. Passou a ocorrer, assim, desvio e exagero na utilização da ação cautelar inominada, que passou a servir de instrumento para a postulação de tutela satisfativa, e não simplesmente acautelatória.

Diante de tal cenário, surgiu a Lei 8.952/1994 que instituiu no CPC/1973 a figura da tutela antecipada, permitindo-se ao juiz, com base num juízo de probabilidade, conceder, desde logo, uma tutela provisória, da mesma natureza daquela que muito provavelmente será outorgada a final, eliminando-se com isso os efeitos da espera por uma cognição exauriente. Deste modo, o legislador infraconstitucional, através da referida lei, conferiu nova redação ao art. 273 do CPC/1973, que passou a disciplinar o instituto da seguinte forma:

Art. 273, CPC/1973. O juiz poderá, a requerimento da parte, antecipar, total ou parcialmente, os efeitos da tutela pretendida no pedido inicial, desde que, existindo prova inequívoca, se convença da verossimilhança da alegação e: I - haja fundado receio de dano irreparável ou de difícil reparação; ou

II - fique caracterizado o abuso de direito de defesa ou o manifesto propósito protelatório do réu.

$\S 1^{\circ}$. Na decisão que antecipar a tutela, o juiz indicará, de modo claro e preciso, as razões do seu convencimento.

$\S 2^{\circ}$. Não se concederá a antecipação da tutela quando houver perigo de irreversibilidade do provimento antecipado.

$\S 3^{\circ}$. A execução da tutela antecipada observará, no que couber, o disposto nos incisos II e III do art. 588.

$\S 4^{\circ}$. A tutela antecipada poderá ser revogada ou modificada a qualquer tempo, em decisão fundamentada.

$\S 5^{\circ}$. Concedida ou não a antecipação da tutela, prosseguirá o processo até final julgamento.

A Lei 8.952/1994 (Brasil, 1994) foi fortemente influenciada pela obra de Luiz Guilherme Marinoni, de 1992 - Tutela Cautelar e Tutela Antecipada -, em que o processualista passou a defender e enxergar, à luz da Constituição, o direito à antecipação dos efeitos da tutela. Defendia Marinoni, na época, que o tempo de duração do processo não pode servir de empecilho à realização do direito da parte, razão pela qual a antecipação da tutela seria um elemento do direito à adequada tutela jurisdicional no plano constitucional.

A nova lei produziu uma notável mudança de concepção no próprio sistema processual. As medidas antecipatórias até então previstas para apenas determinados procedimentos especiais, passaram a constituir providência alcançável em qualquer processo (Zavascki, 2005, p. 70).

Zavascki (1996) observava que a orientação da Lei 8.952/1994 foi clara: admitiu explicitamente a possibilidade de concessão de medidas de antecipação do próprio direito material afirmado pelo autor, mas deu a tal espécie de tutela uma disciplina processual e procedimental própria, diversa da prevista para as cautelares. Com a inserção do instrumento da tutela antecipada, houve uma "limpeza" do processo cautelar, uma vez que se passou a admitir, nas cautelares, somente as medidas que asseguram o direito, sem satisfazê-lo. Todas as demais medidas assecuratórias, que constituam satisfação antecipada de efeitos da tutela de mérito, já não mais cabiam em ação cautelar, devendo ser reclamadas na própria ação de conhecimento.

Portanto, o sistema então em vigor passou a diferenciar a tutela antecipada, regulamentada no art. 273, da tutela cautelar, prevista no art. 796 e seguintes.

Em breve lição, Didier Jr. (2020, p. 692) explica que a tutela antecipada (ou satisfativa) é aquela que que efetiva o direito material, pressupondo a satisfação de um direito material com a entrega do bem da vida almejado. Por outro lado, a tutela cautelar não visa à satisfação de um direito, mas, sim, a assegurar a sua futura satisfação, protegendo-o.

Em que pese a manifesta intenção do legislador em diferenciar as medidas cautelares das antecipadas, o fato é que nem sempre era possível, à luz do caso concreto, se estabelecer qual das medidas deveria ser aplicada. Tanto é que, posteriormente, a Lei 10.444/2002 (Brasil, 2002) inseriu o $\$ 7^{\circ}$ no artigo 273 do $\mathrm{CPC} / 1973$, passando a prever a possibilidade de fungibilidade entre a tutela antecipada e a tutela cautelar. 


\subsection{O CPC 2015 e a Tutela Da Evidência}

O Código de Processo Civil de 2015 alterou substancialmente o regime da tutela antecipada e da tutela cautelar. Ambas foram unificadas no livro V da Parte Geral do CPC/2015, agora denominado de tutela provisória.

Marinoni (2017b, p. 134) apresenta severas críticas à terminologia e ao procedimento adotado pelo CPC/2015:

Essa conjugação foi feita em um determinado momento da história pelo instituto da tutela antecipada - que agora encontra uma pálida e pobre tradução na designação "tutela provisória" empregada pelo legislador (arts. 294 a 311). Ao preferi-la, o legislador deu diversos passos atrás e optou ver o processo por uma perspectiva interna de análise em detrimento de uma preocupação com a efetiva tutela dos direitos. A adoção da terminologia empregada pelo legislador deixa na sombra aquilo que mais interessa para quem vai ao processo - a busca pela tutela do direito. Ao falar em tutelas provisórias o legislador imagina mais uma vez - voltando mais de cem anos na história do processo civil - que é possível tratar o direito material com uma categoria interna, única e invariável que não fornece qualquer pista a respeito dos pressupostos materiais que devem ser alegados e provados para a proteção do direito material. Aludir simplesmente a tutelas provisórias e a tutelas sumárias - e aos conceitos correlatos de tutelas definitivas e tutelas exaurientes - sem iluminá-las com o conceito de tutela dos direitos é perder de vista aquilo que a parte efetivamente foi procurar no processo. É fazer com que o legislador falte com o seu dever de legislar de modo a guiar a ação dos juízes e dos advogados para prestação de uma adequada, efetiva e tempestiva tutela jurisdicional dos direitos"

A nova lei adjetiva civil instituiu como gênero as tutelas provisórias, possuindo duas espécies: (a) a tutela de urgência e (b) a tutela de evidência. Quanto às tutelas de urgência, estas foram subdivididas em tutela antecipada e tutela cautelar, podendo ambas serem requeridas de forma antecedente (antes da propositura da demanda) ou incidental.

Na concepção de Medina (2020a, p. 485), a tutela de evidência também poderá ser concedida em caráter antecedente ou incidental, isso é, antes de apresentado o pedido "principal" (cujos efeitos se vão antecipar, ou cuja produção de efeitos se pretende garantir) ou quando já realizado tal pedido.

Os requisitos da tutela de urgência também foram unificados, acabando-se com a vasta discussão existente na égide do CPC/1973 sobre a eventual diferença entre os requisitos da tutela antecipada e da tutela cautelar.

O art. 300 do CPC/2015 prevê que para a concessão de qualquer tutela provisória de urgência é necessária a demonstração de dois requisitos: (a) a probabilidade do direito; e (b) o perigo de dano ou risco ao resultado útil do processo.

Daniel Neves (2020) apresenta uma sistematização distinta acerca dos requisitos da tutela provisória. Leciona que os requisitos podem ser divididos em três: (i) concedida mediante cognição sumária, ou seja, quando concedida não terá acesso a todos os elementos de conviçção; (ii) probabilidade do direito, justamente por ainda não haver todos os elementos de convicção, o juiz quando decide uma tutela provisória, apenas se decide apenas na probabilidade do direito existir, nunca, portanto, sendo exigida a certeza deste direito para a concessão da tutela provisória; e (iii) substituição da tutela provisória por uma tutela definitiva, ou seja, cedo ou tarde a tutela provisória concedida será substituída pela definitiva (revogando-se, confirmando-se ou modificando-se a tutela provisória).

A própria exposição de motivos do CPC/2015 (Brasil, 2010) deixou clara a intenção do legislador em possibilitar a concessão de tutela de urgência e de evidência. Considerou-se conveniente esclarecer de forma expressa que a resposta do Poder Judiciário deve ser rápida não só em situações em que a urgência decorre do risco de ineficácia do processo e do eventual perecimento do próprio direito, mas também em hipóteses em que as alegações da parte se revelam de juridicidade ostensiva, estas, independente de periculum in mora, por não haver razão relevante para a espera, até porque, em via de regra, a demora do processo gera agravamento do dano.

Para Araújo (2016, p. 952-955), com o advento do CPC/2015, houve um rompimento topológico e estrutural com o CPC/1973 em dois pontos básicos e essenciais. O primeiro referente à eliminação do livro autônomo dedicado ao processo cautelar. Ou seja, houve a extinção formal do processo cautelar no texto legal, considerando que agora a medida cautelar foi inserida no capítulo da tutela provisória. Já o segundo ponto de ruptura refere-se à previsão autônoma da tutela de evidência. 
Para parte da doutrina, ainda que o CPC/2015 tenha sistematizado e dedicado um capítulo próprio para a tutela de evidência, o fato é que esse instituto não nasceu com a lei processual civil de 2015. O CPC/1973 já trazia a previsão de figura que o CPC/2015 viria a tratar como modalidade de tutela de evidência no art. 273, caput, II (nas hipóteses de abuso de direito de defesa ou o manifesto propósito protelatório do réu). Também era considerada, para parcela da doutrina, algo aproximado da tutela de evidência a figura prevista no $\S 6^{\circ}$ (inserido pela Lei 10.444/2002), que permitia a antecipação de tutela quando os pedidos formulados, ou parcela deles, se tornassem incontroversos na relação processual (Araujo, 2016, p. 954-955).

Essa hipótese do antigo $\$ 6^{\circ}$ do art. 273 do CPC/1973 foi transformada pelo CPC/2015 em situação de julgamento parcial, com ou sem resolução do mérito - art. 354, parágrafo único e art. 356. (Araujo, 2016, p. 954-955). Essas situações, ainda que não sejam consideradas modalidades de tutela de evidência, são, inegavelmente, figuras que rompiam com aquela ideia tradicional, de que a prolação de decisões satisfativas somente poderia se dar em uma sentença final.

O que se observa é que o surgimento da tutela de evidência no direito brasileiro foi oriundo da evolução dos institutos existentes, diante das necessidades sociais. Passou a perceber-se que é injusto fazer a parte que tem alta probabilidade de um direito, aguardar até o julgamento definitivo para ter o direito tutelado (Lessa, 2018, p. 301-329).

O CPC/2015 assim estruturou a tutela de evidência:

Art. 311, CPC/2015. A tutela da evidência será concedida, independentemente da demonstração de perigo de dano ou de risco ao resultado útil do processo, quando:

I - ficar caracterizado o abuso do direito de defesa ou o manifesto propósito protelatório da parte;

II - as alegações de fato puderem ser comprovadas apenas documentalmente e houver tese firmada em julgamento de casos repetitivos ou em súmula vinculante;

III - se tratar de pedido reipersecutório fundado em prova documental adequada do contrato de depósito, caso em que será decretada a ordem de entrega do objeto custodiado, sob cominação de multa;

IV - a petição inicial for instruída com prova documental suficiente dos fatos constitutivos do direito do autor, a que o réu não oponha prova capaz de gerar dúvida razoável.

Parágrafo único. Nas hipóteses dos incisos II e III, o juiz poderá decidir liminarmente.

Cambi e Schmitz (2020, p. 159-201) explicam que a tutela da evidência é uma forma de antecipação da tutela fundada unicamente na probabilidade do direito do autor. Independe do periculum in mora. É uma tutela que se destina a repartir o dano marginal do processo entre as partes da relação processual, a fim de que o tempo do processo não recaia unicamente sobre o demandante.

Segundo Medina (2020a, p. 534) o legislador enalteceu aquilo que na doutrina se tem chamado de tutela de evidência sem urgência ou tutela de evidência pura, que corresponde à tutela de um direito que, de tão claro, impele a uma rápida proteção jurisdicional, hipótese em que, embora não haja o risco de dano à esfera jurídica do autor, o juiz decide conceder a tutela em face da certeza ou quase certeza do direito alegado.

Como bem sintetiza Marinoni (2017a, p. 34), o fundamento e a finalidade da tutela de evidência se diferenciam da tutela da urgência. Nesta última, o fundamento é a urgência e a finalidade é evitar o dano; já na primeira, o fundamento é a evidência do direito e a finalidade é a inversão do ônus do tempo no processo.

Em obra clássica sobre a tutela de evidência, Luiz Fux (2000, p. 23-43), assevera que os direitos evidentes são situações em que se opera mais que o fumus boni juris, mas a probabilidade de certeza do direito alegado, aliada à injustificada demora do processo ordinário até a satisfação do interesse do demandante.

Não nos parece tão adequado o termo "probabilidade de certeza do direito" utilizado por Luiz Fux. Pensamos que talvez fosse mais apropriado dizer que a concessão de tutela de evidência exige uma probabilidade do direito qualificada, ou seja, algo além do fumus boni iuris requerido na tutela de urgência (pois ou há probabilidade do direito ou há certeza). 
Ressalta-se: não existe urgência. A tutela da evidência é uma forma de tutela provisória que independe de risco de dano, conforme se extrai do caput do art. 311. Caso exista risco de dano ou ao resultado útil do processo (o periculum in mora), pode ser caso de concessão de uma das tutelas de urgência, mas tal perigo na demora é irrelevante à eventual concessão de tutela da evidência. (Rodrigues e Rangel, 2017, p. 257-276).

Didier Jr. (2020, p. 757) explica que a evidência não é um tipo de tutela jurisdicional. A evidência é fato jurídico processual que autoriza que se conceda uma tutela jurisdicional, mediante técnica de tutela diferenciada. É um pressuposto fático de uma técnica processual para a obtenção da tutela. É uma técnica processual, que diferencia o procedimento, em razão da evidência com que determinadas alegações se apresentam em juízo. Assim, a evidência pode servir às tutelas definitivas ou provisórias.

A tutela da evidência é fundada em cognição sumária, e pode ser concedida liminarmente. Porém, isso não elimina a análise judicial posterior, em caráter definitivo e exauriente do direito buscado (Cambi e Schmitz, 2020, p. 159-201).

$\mathrm{Na}$ essência, o instituto da tutela da evidência consagra a justa distribuição do ônus do tempo no processo, uma vez que, quando o direito que se busca assegurar é claro e evidente, não há justificativa para a demora na prestação jurisdicional (Balus, 2021, p. 171-192).

Nessa ótica, diversas situações podem ser abarcadas pela tutela da evidência. Basta analisar o próprio CPC/2015 para identificar algumas espécies "típicas" de tutela de evidência que não aquelas previstas no art. 311 do CPC, o que desde já induz que o rol é meramente exemplificativo. Vejamos alguns exemplos:

(i) Embargos de Terceiro: $\mathrm{O}$ art. 678 do CPC/2015 prevê que "A decisão que reconhecer suficientemente provado o domínio ou a posse determinará a suspensão das medidas constritivas sobre os bens litigiosos objeto dos embargos, bem como a manutenção ou a reintegração provisória da posse, se o embargante a houver requerido". Nota-se neste caso, basta a prova do domínio e da posse para a concessão da tutela de evidência.

(ii) Ação Monitória: O art. 701 do CPC/2015 dispõe que "Sendo evidente o direito do autor, o juiz deferirá a expedição do mandado de pagamento, de entrega de coisa ou para execução de obrigação de fazer ou de não fazer [...]". Portanto, a decisão que determina a expedição do mandado monitório trata-se de uma clara tutela de evidência. Ressalta-se que, já reconhecia Fux (2000, p. 23-43), há duas décadas, que a "tutela da evidência apresenta semelhanças com o processo monitório documental, mas dele se afasta porque o deferimento liminar não se altera diante da resposta".

(iii) Ação Possessória: O art. 562 prevê que, em caso de comprovação dos requisitos do art. 561 (posse, que houve turbação esbulho ou ameaça, que ocorreu a menos de ano e dia e que perdeu a posse ou ameaça à perda da posse), o juiz deferirá, sem ouvir o réu, mandado liminar de manutenção ou reintegração de posse.

(iv) Inventário: $\mathrm{O}$ art. 647, parágrafo único, do CPC/2015 prevê a possibilidade de uso e fruição imediato de um bem na hipótese de probabilidade que este bem será de quinhão do herdeiro que já poderá se aproveitar imediatamente do bem.

Também se admite a concessão de tutela de evidência em procedimentos regidos por leis especiais, como por exemplo no caso de ação civil pública e de mandado de segurança (Medina, 2020b, p. 549). Nesse sentido o enunciado 49 da CEJ/CJF: A tutela da evidência pode ser concedida em mandado de segurança.

Observa-se que todos os casos acima citados se tratam de tutelas de evidência. Neles não se exige a comprovação de urgência ou perigo, sendo que, para cada caso, os requisitos são próprios.

No entanto, para a concessão de tutela de evidência, o juiz, ainda que presente diversos elementos acerca da evidência do direito do autor, não pode superar, por meios próprios, certos índices de certeza que não se alcançam alguns setores do conhecimento humano, por deficiência de meios técnicos de comprovação absoluta, como por exemplo, a prova da paternidade, que somente pode ser auferível através de exame de DNA (Fux, 2000, p. 23-43). 


\subsection{A Tutela De Evidência e a Prática Forense: Efetividade Versus Desuso}

Embora o CPC/2015 tenha destinado um capítulo próprio para a tutela de evidência, ressaltando a sua existência, o fato é que o instituto raramente tem sido utilizado, talvez por uma questão cultural e/ou por ainda não vislumbrada a efetividade do instrumento.

Não obstante, a tutela da evidência já se demonstra efetiva por sua simples essência: a inversão do ônus do tempo. Por óbvio, ao se inverter o ônus do tempo no processo, a probabilidade de comportamento protelatório pelo réu se reduz drasticamente. Pelo contrário, o que de fato se observa é que nesses casos o réu passa a também buscar a rápida solução do litígio, muitas vezes buscando um acordo, de modo a cessar os efeitos da decisão dada em seu desfavor. Consequentemente, a concessão da tutela da evidência acaba proporcionando celeridade processual, uma vez que as duas partes passam a buscar a solução do litígio.

É notável a efetividade da tutela da evidência.

Passamos a analisar algumas hipóteses que demonstram as vantagens da utilização do instituto, das quais pode se valer o operador do direito.

\subsubsection{O abuso do direito de defesa ou o manifesto propósito protelatório da parte (art. 311, inc. I, CPC)}

A esses atos de deslealdade processual, ou litigância de má-fé, o Código de Processo Civil de 1973 já atribuía o efeito de autorizar a antecipação de tutela, condicionada expressamente a uma prova inequívoca das alegações do autor e da verossimilhança das alegações - art. 273, caput (Dinamarco, 2020a, p. 203).

Trata-se do que a doutrina denomina de tutela de evidência punitiva ou tutela provisória sancionatória, por força da qual a aceleração do resultado do processo se apresenta como uma sanção imposta àquele demandado que exerce seu direito de defesa de forma abusiva, com o único intuito de protelar o andamento do processo. É uma técnica de antecipação da tutela perfeitamente compatível com a garantia constitucional de duração razoável do processo (Câmara, 2017, p. 154).

Ressalta-se, ainda, que o abuso ou a prática de atos protelatórios são passíveis à condenação por litigância de má-fé (art. 77 e 80 do CPC). Ou seja, as condutas do inciso I do art. 311 podem conduzir não só à concessão da tutela provisória punitiva (ou sancionatória), mas também à condenação por litigância de má-fé.

Segundo Bruno Vasconcelos Carrilho Lopes, é vedada no nosso ordenamento a aplicação de mais de uma sanção processual punitiva para sancionar um mesmo ato (ne bis in idem). Assim ocorrendo situação na qual potencialmente incida a tutela antecipada sancionatória e outra sanção processual, aquela prevalece, por critério de especialidade. No entanto, nos parece mais acertada a conclusão de Fredie Didier Jr. (2020, p. 763):

$\mathrm{O}$ ato ilícito pode ter múltipla consequência jurídica, sem qualquer impedimento teórico neste sentido. Uma mesma conduta pode repercutir nos âmbitos cível, penal e administrativo. O art. 77, §2 $2^{\circ}$ e o art. 774 do CPC são expressos em admitir a cumulação de sanções processuais. $\mathrm{O}$ atentado é ilícito processual com múltiplas consequências (art. 77, $\S 7^{\circ}$ do CPC). Nada impede, então, que a conduta da parte implique a tutela de evidência punitiva e a punição pecuniária pela litigância de má-fé.

Exemplifica Araújo (2016, p. 1013):

O autor pode ter negada a liminar possessória pelo fato de não ter ingressado com a ação possessória no prazo de ano e dia (art. 558 do CPC). No entanto, ultrapassado o prazo de ano e dia, a demanda não perde o caráter possessório. O autor, quando titular de pretensão publiciana (posse hábil para fins de usucapião), mesmo esbulhado, terá procedência no pleito final, pela demonstração de sua posse qualificada, ou seja, da melhor posse. O réu, antevendo a perda do processo e a necessidade de retirada da área, inicia uma série de pedidos e incidentes com o fim de protelar o desfecho do processo. Nada impedirá que ao autor pleiteie a concessão da tutela de evidência pelo art. 311, I, do CPC, ainda 
que não tenha demonstrado a urgência, nos termos do art. 300, inclusive por que deixou o réu permanecer na área por mais de ano e dia.

Didier Jr. (2020, p. 763) apresenta outros exemplos de abuso ou atos protelatórios: (i) reiterada retenção dos autos (em caso de autos físicos) por tempo delongado; (ii) fornecimento de endereços inexatos a fim de embaraçar intimações; (iii) prestar informações erradas; (iv) embaraçar a produção de provas; (v) alienação de bens necessários à satisfação do demandante; (vi) repetir requerimento antes indeferido; etc.

Para Cambi e Schmitz (2021, p. 151-196), também se configura abuso do direito de defesa o réu que, na tentativa de se afastar a aplicação de um precedente invocado pela parte requerente, apresenta razões totalmente impróprias, somente para apresentar alguma forma de resistência, ainda que absolutamente inútil. Quanto às condutas caracterizadas de atos protelatórios, trazem alguns exemplos: indicação de endereço errado para inviabilizar intimação; não pagamento de custas processuais para gerar a prática de um ato processual; interposição de incidentes descabidos para suspender o processo principal.

Todas as referidas situações (além de diversas outras), por se caracterizarem em abusos de defesa ou atos protelatórios, permitem tratar como evidente o direito afirmado, razão pela qual podem perfeitamente ser objeto de concessão de tutela da evidência em favor do autor, o que fortalecerá a sua posição jurídica na demanda.

\subsubsection{Fatos comprovados documentalmente associados à tese jurídica pacificada na jurisprudência (art. 311, inc. II,} CPC)

A hipótese do inciso II do art. 311 se trata de tutela de evidência admitida mediante o preenchimento de dois pressupostos, um de fato e outro de direito, respectivamente. O primeiro deles é a existência de prova documental das alegações de fato da parte requerente; e o segundo é a probabilidade de acolhimento da pretensão processual, que se configura exatamente em razão do fundamento normativo da demanda consistir em tese jurídica já firmada em precedente obrigatório (Didier Jr., 2020, p. 765).

Embora a lei refira-se apenas a tese firmada em recurso repetitivo ou súmula vinculante, entende-se que o dispositivo também se aplica à tese firmada em incidente de assunção de competência ou em outras súmulas (ainda que não vinculantes), bem como em julgamento de recurso extraordinário com repercussão geral reconhecida ou em decisão proferida pelo STF em controle concentrado de constitucionalidade (Medina, 2020b, p. 550).

Há manifesta incongruência do legislador ao elencar apenas duas hipóteses de precedentes no art. 311, inciso II. Essa inconsistência ocorre porque o legislador, embora tenha arrolado cinco incisos que referem diferentes modelos de precedentes no art. 927, apenas considerou a existência de dois deles para a autorização da concessão da tutela da evidência. Causa estranheza, portanto, que os precedentes constantes da lista do art. 927 sejam de observância obrigatória por juízes e tribunais mas não sejam dotados de força suficiente - isto é, vinculação suficiente - para, aliados à prova documental, autorizarem a concessão da tutela da evidência (Balus, 2021, p. 171-192).

Nesse sentido, os seguintes enunciados: (i) Enunciado 30, ENFAM (Brasil, 2015): É possível a concessão da tutela de evidência prevista no art. 311, II, do CPC/2015 quando a pretensão autoral estiver de acordo com orientação firmada pelo Supremo Tribunal Federal em sede de controle abstrato de constitucionalidade ou com tese prevista em súmula dos tribunais, independentemente de caráter vinculante; (ii) Enunciado 48, CJF (Brasil, 2017): É admissível a tutela provisória da evidência, prevista no art. 311, II, do CPC, também em casos de tese firmada em repercussão geral ou em súmulas dos tribunais superiores. (iii) Enunciado 135, CJF (Brasil, 2017): admissível a concessão de tutela da evidência fundada em tese firmada em incidente de assunção de competência. 
Por lógica, se a pretensão contrária à precedente vinculante é julgada liminarmente improcedente (art. 332, CPC), a pretensão de acordo com precedente vinculante deve ser julgada liminarmente procedente, ou seja, a tutela de evidência deve ser concedida em tais casos (Nejaim, 2020). Tanto é que o parágrafo único do art. 311 permite a concessão liminar da tutela de evidência fundada no inciso II do art. 311.

No entanto, observa Dinamarco (2020a, p. 203), no caso de prova inequívoca do direito atrelada com precedente de alta idoneidade, a concessão de uma mera tutela provisória colidiria com o disposto no art. 355 do CPC, que autoriza uma medida muito mais energética para esses mesmos casos, que é o julgamento antecipado do mérito. Nestes casos, para Cassio Scarpinella Bueno (2018, p. 429), a grande utilidade da concessão da tutela da evidência reside em "tirar" ou evitar o efeito suspensivo da apelação, conferindo eficácia imediata à sentença. Todavia, como bem observado por Fábio Caldas de Araújo (2016, p. 955), a concepção do julgamento antecipado parcial como julgamento provisório torna obrigatória para o magistrado a confirmação, na sentença final, da antecipação parcial do mérito mesmo em face de pedido incontroverso.

Ora, se o direito do autor está lastreado em precedente vinculante e devidamente comprovado documentadamente, por que esperar o trâmite integral de um processo judicial, para somente na sentença ter o direito reconhecido? Aqui reside a eficácia da tutela da evidência, embora pouco utilizada. O operador pode se valer da tutela de evidência satisfativa nestes casos, obtendo antecipadamente uma decisão judicial a seu favor.

\subsubsection{Prova documental suficiente dos fatos constitutivos do direito do autor, a que o réu não oponha prova capaz de gerar dúvida razoável (art. 311, inc. IV, CPC)}

A tutela provisória fundada no inciso IV do art. 311 do CPC se aproxima do julgamento antecipado do mérito (art. 355, CPC). Os fatos e os direitos foram contestados pelo réu, contudo, a defesa foi insuficiente para criar imprecisão e dubiedade às narrativas do autor, ou seja, a contestação foi incapaz de levantar obstáculo confiável (Cambi e Schmitz, 2020, p. 159-201).

No entanto, diferem-se por alguns aspectos. O principal, talvez, seja o fato de que no julgamento antecipado do mérito, todas provas necessárias já foram produzidas, portanto, a decisão se dá em cognição exauriente. Já na tutela da evidência, a cognição é sumária, visto que ainda há a possibilidade de produção de novas provas. Em razão disso, a tutela da evidência se dá por decisão provisória, que deve ser confirmada em sentença, já que ainda pode haver mudança no entendimento do magistrado - observando-se que a tutela da evidência também pode ser concedida na própria sentença, em cognição exauriente, como será abordado no tópico seguinte.

Leciona Fábio Caldas de Araújo (2016, p. 1014-1015), que o art. 311, IV, do CPC permite que a tutela da evidência seja concedida com base em prova sumária documental. A prova sumária deverá permitir a formação da convicção quanto ao direito quanto ao direito afirmado de modo imediato e com formação de juízo de aparência que permita a apreciação imediata sobre os fatos apontados.

Araújo (2016, p. 1015) cita três exemplos:

Um exemplo simples poderá ilustrar a afirmação, como a infecção de uma pessoa por transfusão de sangue após a realização de uma cirurgia. Os exames de internação demonstravam exames de sangue normais, e após a cirurgia detecta-se a contaminação. O direito postulado será evidente. [...] Em situações de apreciação simples e imediata o juiz poderá conceder a tutela da evidência mesmo sem a necessidade de manifestação prévia do réu. Tudo depende do conjunto probatório ofertado. A decadência do mandado de segurança pelo esgotamento do prazo de 120 dias revela um possível exemplo. $\mathrm{O}$ atraso na propositura não elimina a situação de evidência que pode estar demonstrada pela peça inicial. [...] A aquisição a non domino pode revelar hipótese de sua aplicação para impedir pretensão reivindicatória quando a posição do réu esteja reforçada pelo registro da propriedade (art. 1.242, parágrafo único, do CC). A fungibilidade permitirá que a medida assuma, no mínimo, caráter protetivo. Aquele que já está há mais de 
cinco anos na posse de bem adquirido de modo oneroso tem o direito de permanecer na situação fática consolidada pelo menos até o transcurso da ação petitória com a definição sobre a situação possessória registral.

Outro exemplo é apresentado por Fux (2000, p. 23-43), citando um julgamento proferido pela Corte Superior: um cidadão adquiriu imóvel mobiliado, por escritura pública, tendo pago o preço adiantado no ato da escritura, conforme lavrado pelo notário. Sessenta dias após aguardar a mobília em seu imóvel ingressou em juízo alegando que, por força do negócio pago adiantadamente, desfizera-se de todos os seus móveis de seu imóvel, por isso encontrava-se em dificuldades, sem dispor de uma residência mobiliada conforme o pactuado e quitado. O exemplo não se trata de medida cautelar, considerando que não há qualquer risco para a utilidade futura do processo, sendo caso de tutela de evidência.

O caso, em essência, reclamava uma providência "justa" o sentido de não revelar-se razoável que um jurisdicionado, portador de um direito líquido e certo como o inserido na escritura, tivesse de aguardar as delongas do procedimento ordinário para a definição do seu direito, superando a instância recursal, para após executar a obrigação de fazer com todas as alternativas previstas, com o que, de certo, obteria a realizabilidade prática de sua pretensão após bons longos anos (Fux, 2000, p. 23-43).

\subsubsection{A concessão de tutela de evidência na sentença}

Especialmente nos casos de cognição exauriente, ou seja, mediante esgotamento das iniciativas probatórias, a concessão da tutela provisória possui grande valia, uma vez que permite que o jurisdicionado se beneficie imediatamente dos efeitos da sentença, inclusive mediante cumprimento provisório, já que a apelação cabível contra sentença que concede, confirma ou revoga a tutela provisória, nesse ponto, não é dotada de efeito suspensivo (Marcondes, 2020, p. 283-302).

Em outras palavras, a tutela provisória concedida em sentença retira o efeito suspensivo do recurso de apelação, por força do art. 1012, $\S 1^{\circ}, \mathrm{V}$, do CPC que prevê que os efeitos da sentença que confirma, concede ou revoga tutela provisória começam imediatamente após a sua publicação, isto é, quando a tutela provisória é concedida em sentença, o recurso de apelação não é dotado de efeito suspensivo (Cambi \& Schmitz, 2020, p. 159-201).

Ou seja, ao se estar diante de situação passível de concessão de tutela de evidência (v.g., contestação infundada ou prática de algum ato protelatório), é proveitoso ao operador requerer, antes da sentença, que lhe seja concedida tutela da evidência, para que, dessa forma, seja possível a execução imediata (ainda que de forma provisória). Frisa-se que o requerimento de tutela da evidência deve ser formulado e apreciado até o momento da sentença, uma vez que, após a sentença, é defeso ao juiz conhecer de qualquer pedido, com exceção de inexatidões materiais ou erros de cálculo (art. 494, CPC).

\section{Conclusão}

A tutela da evidência não se trata de instrumento novo no ordenamento jurídico brasileiro, sendo que já havia previsão desde o CPC/1973 e em leis especiais, embora não disciplinada em um artigo/capítulo próprio.

O CPC/2015 veio a disciplinar o tema expressamente, em seu art. 311. Não obstante, o instituto raramente vem sendo utilizado na prática forense, talvez por razões culturais, uma vez que a comunidade jurídica está acostumada a valer-se da tutela de urgência em todos os casos que demandam de uma proteção sumária do direito.

Os incisos I e IV do art. 311 dão azo a diversas situações que podem ser tuteladas pela evidência. No entanto, vale ressaltar que a tutela de evidência não se exaure no art. 311, vez que diversas modalidades estão espalhadas não só pelo CPC/2015, mas também em leis especiais. 
A essência da tutela da evidência é a inversão do ônus do tempo no processo, de modo que, ao se proferir uma decisão favorável ao autor, quando apresentado um direito manifesto, busca-se dividir os prejuízos causados pela morosidade processual, já que o réu passa a ter uma decisão produzindo efeitos em seu desfavor.

A partir deste trabalho, nos parece correto induzir que os próximos estudos sobre a tutela da evidência devam se pautar na principal característica do instituto: a inversão do ônus do tempo no processo. Isso pois, além de se tratar da essência do instituto, a inversão do ônus do tempo possui um significante efeito prático, que tem grande potencial de chamar a atenção dos operadores do direito a esse instrumento tão pouco utilizado.

Talvez com uma pesquisa focada em evidenciar o aspecto prático do instituto, a tutela de evidência passe a não mais se tornar um instituto meramente acadêmico, fazendo com que os operadores passem a enxergar a utilidade do instrumento, trazendo efetividade e maior celeridade na prestação jurisdicional.

\section{Referências}

Araujo, F. C. (2016). Curso de processo civil: parte geral. Malheiros.

Balus, L. C. (2021). Tutela da evidência, precedentes judiciais e a necessidade de uma interpretação extensiva da norma do art. 311 , II, do CPC. Revista de Processo. (314), 171-92.

Brasil. (1939). Código de Processo Civil de 1939 - Decreto-Lei 1.608/1939. http://www.planalto.gov.br/ccivil_03/Decreto-Lei/1937-1946/Del1608.htm.

Brasil. (1973). Código de Processo Civil de 1973 - Lei 5.869/1973. http://www.planalto.gov.br/ccivil_03/leis/15869impressao.htm.

Brasil. (1994). Lei 8.952/1994. http://www.planalto.gov.br/ccivil_03/leis/18952.htm.

Brasil. (2002). Lei 10.444/2002. http://www.planalto.gov.br/ccivil_03/leis/2002/110444.htm.

Brasil. (2010). Anteprojeto do Novo Código de Processo Civil de 2015. https://www.conjur.com.br/dl/anteprojeto-cpc-parte1.pdf.

Brasil. (2015). Código de Processo Civil de 2015 - Lei 13.105/2015. http://www.planalto.gov.br/ccivil_03/_Ato2015-2018/2015/Lei/L13105.htm.

Brasil. (2015). Enunciados da Escola Nacional de Aperfeiçoamento de Magistrados (ENFAM). https://www.enfam.jus.br/wpcontent/uploads/2015/09/ENUNCIADOS-VERS\%C3\%83O-DEFINITIVA-.pdf.

Brasil. (2017). Enunciados da Jornada de Direito Processual Civil do Centro de Estudos Judiciários do Conselho da Justiça Federal (CEJ/CJF). https://www.cjf.jus.br/cjf/noticias/2017/setembro/copy_of_Enunciadosaprovadosvfpub.pdf.

Buzaid, A. (1977). A Influência de Liebman no Direito Processual Civil Brasileiro. Revista da Faculdade de Direito da Universidade de São Paulo. 72(1).

Câmara, A. F. (2017). O novo processo civil brasileiro. (3a ed.), Atlas.

Cambi, E., \& Schmitz, N. (2020). Questões procedimentais da tutela de evidência. Revista de Processo. (1017), $159-201$.

Cambi, E., \& Schmitz, N. (2021). Tutela de Evidência e Garantia do Contraditório. Revista de Processo. (317), 151-96.

Carvalho, T. R. de. (2017). Primeiras Linhas acerca da Tutela Preventiva. Revista de Ciências Jurídicas e Sociais da UNIPAR. (20)1, 13-31.

Didier Jr., F. (2020). Curso de direito processual civil: teoria da prova, direito probatório, decisão, precedente, coisa julgada, processo estrutural e tutela provisória (15a ed.), Ed. JusPodivm.

Dinamarco, C. R. (2020) Teoria geral do processo. (32a ed.), rev. e ampl. Malheiros.

Dinamarco, C. R. (2020). Instituições de direito processual civil: (10a ed.), Malheiros.

Fux, L. (2000). A tutela dos direitos evidentes. Jurisprudência do Superior Tribunal de Justiça. (2)16, 23-43.

https://bdjur.stj.jus.br/jspui/bitstream/2011/894/A_Tutela_Dos_Direitos_Evidentes.pdf.

Lessa, G. T. (2018). Perfil Histórico-Dogmático da Tutela de Evidência: A Gênese do Instituto no Direito Processual Civil Brasileiro. Revista de Processo Comparado. (08) 301-29.

Marcondes, G. (2020). Tutela provisória da evidência e duração razoável do processo. Revista dos Tribunais. (1013), $283-302$.

Marinoni, L. G. (2017). Tutela de urgência e tutela da evidência: soluções processuais diante do tempo na justiça. Revista dos Tribunais.

Marinoni, L. G. (2017). Novo curso de processo civil [livro eletrônico]: tutela dos direitos mediante procedimento comum. (3a ed.), Revista dos Tribunais.

Marins, G., Dotti, R., \& Martins, S. G. (2020). A tutela provisória nas lições de Victor A. A. Bomfim Marins. Revista de Processo. (307), 149-57. 
Research, Society and Development, v. 10, n. 17, e98101724361, 2021

(CC BY 4.0) | ISSN 2525-3409 | DOI: http://dx.doi.org/10.33448/rsd-v10i17.24361

Medina, J. M. G. (2020). Curso de direito processual civil moderno. (5a ed.), Thomson Reuters Brasil.

Medina, J. M. G. (2020). Código de Processo Civil comentado. (6a ed.), Thomson Reuters Brasil.

Nejaim, A. C. B. L., \& Neves, D. A. A. (2020). Tutela da Evidência. https://www.youtube.com/watch?v=aTVuxm_BnZA\&ab_channel=ordemadvogadosms

Neves, D. A. A., \& Nejaim, A. C. B. L., (2020). Tutela da Evidência. https://www.youtube.com/watch?v=aTVuxm_BnZA\&ab_channel=ordemadvogadosms.

Rodrigues, M. A., \& Rangel, R. C. (2017). A tutela da evidência como técnica de atuação judicial. Revista de Processo. (271), 257-76.

Strickler, Y. Medidas provisórias justificadas pela urgência e pela evidência. Revista de Processo. (300), 93-106.

Theodoro Junior, H. (2018). Curso de Direito Processual civil. (59a ed.), Forense.

Watanabe, K. (1996). Tutela antecipatória e tutela específica das obrigações de fazer e não fazer. Saraiva.

Zavascki, T. A. (1996). Medidas Cautelares e Medidas Antecipatórias: Técnicas diferentes, função constitucional semelhante. Revista Trimestral de Direito Público. (14). https://core.ac.uk/download/pdf/79058188.pdf.

Zavascki, T. A. (2005). A antecipação da Tutela. (4a ed.), Saraiva. 